\title{
Literary Patriotism in Ecuador's Juan León Mera and Juan de Velasco
}

\author{
Eileen Willingham
}

\begin{abstract}
Nineteenth-century nation builders in Ecuador looked to the past for models of national unity and identity. The prolific writer and government servant Juan León Mera served the theocratic state of ultraconservative President Gabriel García Moreno, whose rule extended from 1860 to 1875 , and contributed to shaping Ecuador's national imaginary in his literary and journalistic output. Mera found many elements for his vision of Catholic triumphalism in Ecuador in the work of eighteenth-century exiled Jesuit historian Juan de Velasco. This article traces genealogical ties between the two writers, from the Creole historian's elite patriotic history La historia del Reino de Quito en la América meridional of 1789 to Mera's many novels, stories and essays.
\end{abstract}

As was the case for other post-independence Spanish-American nations, in Ecuador, the experience of nation building in the nineteenth century was tumultuous. After the independence wars, the colonial-era Audiencia de Quito joined Gran Colombia as the Distrito del Sur (1822-30), but broke away as Bolivar's dream of a unified South American state crumbled. In Ecuador's case, after 1830, conflicts among regions and competing oligarchic interests led to continued instability, as traditional landholding elites in the highlands themselves divided between northern and southern zones - and export-oriented landholders in the coastal region struggled to establish both a nation-state and a sense of nationhood in the ethnically stratified territory. Between 1860 and 1875, as Ecuador was drawn more closely into the global export economy, the nation was ruled by Gabriel García Moreno, who supported his modernising program with a repressive regime closely allied with the Catholic Church. ${ }^{1}$ Writer and government official Juan León Mera made significant contributions to Ecuador's nation-making project, both by backing García Moreno's 'theocratic state' and by shaping Ecuador's sense of national identity through his literary output. ${ }^{2}$ Just as García Moreno looked to colonial models of social control-for example, by renewing the Church's role in 'civilising' the people and by reintroducing colonial-era labour arrangements - to shore up his national project, Mera turned to a late-colonial historian of Quito, Juan de Velasco, as a source of elements of

\footnotetext{
1 Ayala Mora, E. 2005, Resumen de Historia del Ecuador, Corporación Editora Nacional, Quito, pp. 7781; Larson, B. 2003, The Trials of Nation Making. Liberalism, race, and ethnicity in the Andes, 1810-1910, Cambridge University Press, Cambridge, pp. 103-40.

2 Vidal, H. 1980, “'Cumandá": apología del estado teocrático', Revista de Crítica Literaria Latinoamericana, vol. 6, no. 12, pp. 199-212.
} 
national identity. Both writers, living in periods of rapid change, attempt to define the essence of the Quiteño or Ecuadorian people by looking to the past to fashion invented traditions for the present. ${ }^{3}$ Velasco's Historia del Reino de Quito en la América meridional (1789) ${ }^{4}$ and Mera's works show that both promise and contradictions lie at the heart of their patriotic projects.

Velasco's eighteenth-century Creole patriotic history played a vital part in Ecuador's national imaginary during the nineteenth and twentieth centuries. The text was rescued from near oblivion, repatriated from Europe, and published in early republican Ecuador in the 1840s. Post-colonial nationalists found his tale of alternative indigenous agency and Quiteño identity too enticing to resist; in addition, the text provides the prehistory for nationalist rivalry between Ecuador and Peru. Mera's work is deeply indebted to Velasco's history of the Quito region, because of its heroic tale of an indigenous royalty that outshone the Incas; its description of the region's territory, resources and population; and its model for establishing and perfecting Catholic civilisation in America. Mera saw continuity between various periods and actors of his nation's history, as did Velasco with the colonial Kingdom of Quito, and both have been instrumental in institutionalising the unbroken narrative of Ecuadorianness (or 'Quiteñoness') that elites wished to tell. Mera's concerns with national and territorial unity, national origins and cultural history resonate with the earlier attempt by Velasco, written during the Jesuit's exile in Italy after 1767. To take one example, if Mera's 1879 novel, Cumandá, has become a foundational fiction, in the eminently quotable phrase of Doris Sommer, one that has been institutionalised in schools, and in literary and historical texts, Velasco's history has also been seen as foundational - and a fiction. ${ }^{5}$ In short, my analysis of Mera's debts to Velasco both establishes their ties of genealogy and explores and contextualises notions of nation building and literary history in nineteenth-century Ecuador.

In his work, Mera imposes a story of national continuity on the events, people and places that constitute the nation of Ecuador - that is, like Velasco, he desires an unbroken narrative about a place, its people, and its history as continuous, unified, legitimate and providential. How can Mera forge links between his nineteenth-century present and various stages of the past? His project is similar to that of Velasco, and he unites these elements by focusing on how the ancient Kingdom of Quito's people, history and place develop into contemporary Ecuador. He links past and present by showing that the peoples

3 Hobsbawm, E. and Ranger, T. (eds) 1994, The Invention of Tradition, Cambridge University Press, Cambridge.

4 Velasco, J. 1988, Historia del Reino de Quito en la América meridional, [3 vols], Casa de la Cultura Ecuatoriana, Quito.

5 Mera, J. L. [1879] 1976, Cumandá o un drama entre salvajes, (Fifth edition), Espasa-Calpe, Madrid; Sommer, D. 1991, Foundational Fictions. The national romances of Latin America, University of California Press, Berkeley, pp. 1-52, 233-56. 
of Ecuador succeed each other in a historically determined way; they share a patriotic landscape that they have inhabited from time immemorial; and they are also united by language, culture and religion.

Throughout his long career, Mera, a prominent member of Ecuador's lettered city, wrote short and longer fiction on national themes (Cumandá, the stories collected in Novelitas ecuatorianas); poetry (Melodias indigenas, the 'legend' 'La virgen del sol', and poems collected in Cantares del pueblo ecuatoriano); numerous essays published in the national press, as well as literary criticism (Ojeada histórico-crítica de la poesía ecuatoriana); and a history of Gabriel García Moreno's theocratic state and its aftermath. He served in various government positions, including as senator and provincial governor, and wrote the lyrics to Ecuador's national anthem. Mera's patriotic literary project lays cultural and historical foundations for the nation in several ways, and often betrays contradictory impulses. He portrays Ecuador's indigenous cultures in various genres (novel, poetry and essay) and assesses Ecuador's national literary history (in prologues, letters and essays). Mera's literary constructions of the noble savage in Cumandá and the poem 'La virgen del sol' (1861; second edition 1887) contribute images to the national imaginary that, while underscoring the centrality of indigenous peoples to Ecuador's sense of nationhood, also emphasise the Indian's 'pastness'. Mera's treatment of this phenomenon, as theorised by Sommer, Hernán Vidal and others, is in concert with other literary projects linked to the consolidation of the nation throughout Latin America (Zorrilla's Tabaré in Uruguay, Galván's Enriquillo in the Dominican Republic). ${ }^{6}$ Mera's work as literary critic and compiler of poetry, however, complicates his literary enterprise. While his 'Indianist' works Cumandá and 'La virgen del sol' cast a nostalgic backward glance at the modernising nation's mythical forebears and point to a literary solution for unifying the politically, geographically and ethnically stratified nation, Mera's Cantares del pueblo ecuatoriano (1892), Ojeada histórico-crítica de la poesía ecuatoriana (1868), and essays and stories published in periodicals, uncover the presence of a more nuanced dialogue between nostalgia and literary historiography in Ecuador.

Velasco's interpretation of his patria's history establishes a number of patriotic myths and values that later writers and other nation builders have drawn on to shape the nation's identity. The Historia presents Quito with a glorious past in the form of an indigenous dynasty that parallels that of the Incas. Velasco calls that dynasty the Scyris, and he depicts them as authentic shapers of the patria, who enfold various ethnic groups into Quito's territory, and who always exhibit such virtuous characteristics as engaging in just war, and only as a last resort; having an advanced culture and language; and practising a monotheistic religion. He presents the Incas, who conquer the Scyris, but who share a common origin

6 Sommer, Foundational Fictions, pp. 233-56. 
with them, both as outsiders who have descended into idolatry and corrupt governing and as a slightly more civilised people. In short, Quito and its Scyris benefit from the reflected glory of Incan culture, while Quiteños retain such attributes as authenticity, legitimacy, pure religious practices and a tradition of territorial integrity. After narrating the glorious past of the Scyris, Incas and early Spanish conquerors, Velasco redirects his focus to the heroic actions of his expelled Jesuit brethren, whose labours in the vast Amazonian territories dominate his history of the later colonial period. Velasco's history lays out Quito's territorial boundaries, its heroes and myths, its cultural achievements, and its ideal ethnic make-up, and provides a ready-made story of national glory for republican Ecuador.

Mera shared many of Velasco's patriotic concerns. The Jesuit's work was not published until the 1840s in Quito, but contemporary press accounts of the whereabouts of the manuscript and its eventual publication highlight its importance in shaping notions about the character of the new nation. Mera documented his debt to Velasco in many of his works, often through footnotes, and there are many points of contact between the two. Both were poets and literary historians who considered the Quichua language to be an integral component of national culture. Their works exalt idealised past, noble Indians, but also protest present unjust treatment of contemporary indigenous people. And both writers look beyond the confines of the populous highland and coastal regions to the Oriente - the jungle region whose incorporation into the patria they consider vital. Underpinning their concept of the patria is a deep current of Catholic triumphalism in the American context; Velasco and Mera praise the uniqueness of their land and its culture, which, in their view, benefited from the union of American traditions and European civilisation, especially Christianity.

Velasco - as did earlier historians of America - sees the hand of providence in the course of Quito's history, but also feels compelled to defend Catholic humanism and Spanish imperialism against the inroads of certain European eighteenth-century historians, whom he sees as straying from providentialist views. He produces a new patriotic discourse, based on colonial-era elite conceptions of hierarchy, which gives his patria the veneer of an ancient, glorious past. Velasco's history provides his compatriots with a model for an aristocratic, autonomous kingdom, based in Quito and worthy of a place in the Spanish imperial constellation. ${ }^{7}$

Just as Velasco longs for a return to the Hapsburg Pact, Mera casts a nostalgic backward glance at colonial modes of Catholicism. He staunchly defended García Moreno's project of restoring the Church's 'civilising' role in national

7 Cañizares, J. 2001, How to Write the History of the New World. Historiographies, epistemologies, and identities in the eighteenth-century Atlantic world, Stanford University Press, Calif., pp. 360-437. 
life-both in his fiction and in his essays. For example, in the novel Cumandá, Mera narrates a continuous Ecuadorian history that incorporates several historical periods, historical actors, languages, ethnicities, spaces, and territorial boundaries into one conceptual whole, controlled by religious figures. He establishes a clear link with the colonial past, by ascribing contemporary nineteenth-century consequences to the 1767 expulsion. Mera emphasises the violent act of writing that expelled Velasco and his fellow Jesuits: 'Un repentino y espantoso rayo, en forma de pragmática sanction, aniquiló en un instante la obra gigantesca de dilatadisimo tiempo, de indecible abnegación y cruentos sacrificios. ${ }^{8}$ Mera's support for the Jesuits and his adhesion to the theocratic state of the ultraconservative President García Moreno, who brought the Jesuits back to Ecuador, are well known and amply documented. Cumandá shares with Velasco's Historia a rewriting of history that transforms the missionaries into central actors of history, and the jungle into its main stage. The novel's missionary is a Dominican, as Mera chooses to place the action in 1808, after the Jesuits were expelled and clearly before they were welcomed back from Europe by García Moreno in 1862. The year 1808 is a propitious moment; just before the independence struggle, it was a pivotal moment of upheaval in Spain and in America. Thus, the story is positioned between periods; it takes place in a time of colonial transition to the modern, independent nineteenth-century state. But the novel features tropes that continue from one period to the next: noble and savage Indians; rebellion and resolution; Christian redemption; and a sense of the people who inhabit proto-Ecuadorian space as sharing a collective identity. Mera asks the question that Velasco leaves unexpressed:

¡O, qué habría sido hoy del territorio oriental y de sus habitantes al continuar aquella santa labor de los hombres del Evangelio... Habido habría en América una nación civilizada más, donde ahora vagan, a par de las fieras, hordas divorciadas del género humano y que se despedazan entre si. ${ }^{9}$

Mera clearly draws connections between the violence of the royal pen in the colonial period and his nation's present-day situation, in a move that ties the colonial past to present-day Ecuador and presents lessons from history as a critique of the republic.

Catholic triumphalism is also present in Mera's poem 'La virgen del sol', a romantic 'legend' of star-crossed Scyri lovers, which draws heavily on Velasco's Historia, as the copious footnotes in the 1861 first edition and the prologue to the second edition attest. The poem narrates a complicated set of amorous intrigues, which play out against the backdrop of the Incan dynastic civil wars

8 Mera, Cumandá o un drama entre salvajes, p. 49. See also Vidal, ““Cumandá”', p. 206; Sommer, Foundational Fictions, p. 237; Vallejo Corral, R. 2006, Juan León Mera. Pensamiento fundamental, Corporación Editora Nacional, Quito, p. 14.

9 Mera, Cumandá o un drama entre salvajes, p. 49. 
on the eve of the Spanish invasion, and end when the Spaniards occupy Quito in 1533. Mera's figure of the traitorous Scyri general, Rumiñahui, is straight out of Velasco's account of what the Jesuit calls Quito's 'ancient history'; in the second edition of 1887, Mera cites recent historical evidence that challenges Velasco's account of Rumiñahui's last days, but he decides to remain faithful to the Jesuit's story. ${ }^{10}$ Mera's poem excuses the excesses of the Spanish conquistadors by presenting the benign figure of Father Niza, who quickly converts and marries off the Indian protagonists, thus both redeeming them as Catholics and laying claim to the positive effects of Spanish civilisation. ${ }^{11}$ Although Velasco takes the Franciscan Niza to task for overstating the case of Spanish cruelty and thus fuelling foreign criticism of Spain, the eighteenth-century historian's view of the conquest of Quito is similar to Mera's: he attributes atrocities to specific, low-born Spaniards who acted alone, and argues that the ends-bringing Christianity and civilisation to Quito-justify the means. ${ }^{12}$

In his poem, Mera chooses to end the conquest period with a speedy week of catechism and Catholic marriages for the Scyri lovers. In contrast, after recounting the tumult of the conquest and the Spanish civil wars, Velasco closes the volume on Quito's ancient history with a portrait of possible harmony, in which order is assured, towns are founded, good government established, new conquests are carried out, and, above all, the Amerindians are brought into the Christian, civilised fold. In the Spanish official sent to pacify rebellious Spaniards during the revolts of the 1540s, President La Gasca, Velasco has found a transitional heroic figure. Velasco's portrayal of La Gasca foreshadows his descriptions of missionaries heading into the jungle to peacefully win over barbarous Indians. (Velasco's next volume, the Historia moderna, concentrates more on missionary heroics than on the valour of conquerors.) Velasco judges this last period in Quito's ancient history as a time when the need for arms has ended, and instead, La Gasca pacifies the Kingdom of Quito through negotiation and religion. Like Niza before him and the Jesuit missionaries to come, La Gasca essays forth among potential enemies unarmed except for the breviary.

Velasco maintains that La Gasca's mission is the first time that a high-ranking Spanish Government official turns his attention to the welfare of the Indians. Velasco argues that the conquistadors had ignored their duty to convert the Indians until then, and that they had collected tribute from them arbitrarily. He further charges that Indians had been victims of inhumane treatment and that many had died as porters during the Spanish civil wars and conquests and in the mines. In Velasco's version of Quito's history, La Gasca regulates

10 Mera, J. L. 1887, 'La virgen del sol, (leyenda)', in Obras de Juan Leon Mera. Volume 1: Melodías indígenas, Sección Tipográfica del Crédito Catalán, Barcelona.

11 Mera, J. L. 1861, La virgen del sol, leyenda indiana, Imprenta de los Huérfanos de Valencia, Quito, pp. 216-17.

12 Velasco, Historia, vol. 2, pp. 311-13. 
the Indians' instruction, treatment, and tribute burden, and he also fixes the boundaries of the four bishoprics of the area. Velasco approvingly notes that in two short years, La Gasca manages to quell a major uprising, award loyal vassals, procure the common good, assure a generous living to all, and introduce regular government. ${ }^{13}$ According to Velasco, La Gasca leaves behind a colony full of promise, a place where evil has been punished and Christianity flourishes. ${ }^{14}$

In prologues and essays throughout his prolific career, Mera also reflects on America's unique cultural and historical mixture, based on the continent's original inhabitants and its natural surroundings, and perfected by European religion and civilisation. For example, in his prologue to an 1892 anthology of Ecuadorian poets, published to coincide with the quatecentenary of Columbus's discovery of America, Mera links the providentialist, civilising power of Catholicism to his nation's unique literary output. According to Mera, the book serves 'a honrar al Gran Descubridor con la ofrenda de algunos frutos literarios producidos en esta parte del Mundo hallado por él, y por él presentado al bautismo de la regeneradora civilización Cristiana'. ${ }^{15}$ The volume is intended to repay Ecuador's cultural and historical debt to Spain, by demonstrating Ecuadorian literary talent to the world, from 'una parte del mundo que él descubrió e hicieron español las armas de los conquistadores, la palabra y los sacrificios de los misioneros, y la lengua, las costumbres y las leyes de la península ibérica'. ${ }^{16}$

Such pro-Hispanic sentiments tell only half the tale. Mera, like Velasco before him, is interested in explaining his nation's essential characteristics. Velasco's subject is his patria's specific natural and human history from antiquity to the eighteenth century, and he includes Quito's literary and cultural talents as part of his patria's heritage. In standard Romantic fashion, Mera repeatedly seeks to define Ecuador's national soul. One manifestation of this is his frequent defence of American themes, language, customs and natural setting as worthy topics for men of letters to take up. He engaged in numerous debates, with Spanish critics Antonio Rubio y Lluch, Juan Valera and others, ${ }^{17}$ in which he defended introducing American 'novelty' in literature. He lays out his theories in the Ojeada histórico-crítica de la poesía ecuatoriana, and puts them into practice in

\footnotetext{
13 Ibid., p. 440.

14 Velasco concludes that the ends justify the means in the Spanish conquest of Peru: 'Aunque cometieron graves injusticias y violencias contra las naciones indianas, les introdujeron la vida racional, politica y civil; compensándoles con la luz del Evangelio largamente todos los males que les causaron' (Historia, vol. 2, p. 445).

15 Mera, J. L 1892, 'Prólogo', Antología ecuatoriana. Poetas, Imprenta de la Universidad Central, Quito, p. i.

16 Ibid., p. iv.

17 Corrales Pascual, M. 1995, ‘Juan León Mera, crítica e historia literaria: elementos de una visión del munco trágica', in J. Bazos Barrera (ed.), Juan León Mera. Una visión actual, Corporación Editora Nacional, Quito, pp. 15-30; León, C. 2001, Hispanoamérica y sus paradojas en el ideario filosófico de Juan León Mera, Corporación Editora Nacional, Quito, pp. 73-4.
} 
such works as Cumandá, the poetry of Melodias indigenas, and 'La virgen del sol', all of which contain American motifs, Indianist topics and characters, and Quichua terminology.

Velasco, too, relies on his knowledge of Quichua in narrating Quito's history, and demonstrates his privileged mastery of native American knowledge. For example, as part of his natural history of the Quito region, Velasco produces a patriotic taxonomy of its flora and fauna. Faced with the task of categorising the seemingly innumerable plant species of the region, Velasco tries to manage them by reducing them to nine categories based on their utility, such as those useful for medicine, or for their flower or wood, or for various other uses. Velasco gives each plant's name, its meaning in Spanish if it is a Quichua name, a description of the plant and where it is found, and its properties. He often includes an anecdote about the plant's discovery or a notable story of how it has been used, to which he was an eyewitness or for which he relies on the account of suitable witnesses. Velasco often values the Jesuit missionaries' knowledge of Quichua and botany over that of the Indians themselves, or he at least requires the corroboration of such a reliable witness for indigenous knowledge to be codified. Velasco notes that the area's wood varieties, for example, are innumerable, their names only vaguely known by the missionaries in the region. He makes no mention of indigenous naming systems for this subset of the natural world, and states that he must omit many plants because he does not know - or cannot remembertheir names. ${ }^{18}$ Velasco even claims that there are so many edible fruits in hot places that not even the Indians know all the names, let alone the Spanish. ${ }^{19} \mathrm{He}$ sets himself up as the knowledgeable Creole subject, able to mediate between European and American epistemological fields.

Similarly, Mera also positions himself between Ecuador and Europe, as a kind of culture broker who controls several registers. In his prologue to the 1892 anthology, Mera recognises that such works, which showcase the work of 'cultivated intelligences', present an incomplete portrait of Ecuadorian wit ('ingenio') because they neglect the products of the people. Mera, along with a group of like-minded literary men, set out to rectify this one-sided view of national culture, by collecting and publishing Ecuador's popular poetry, in the Cantares del pueblo ecuatoriano (1892). In the collection's prologue, Mera spells out the value of studying such forms of popular expression to arrive at a fuller understanding of Ecuador's history and culture. According to Mera, 'el pueblo ecuatoriano todo lo canta', including politics, history, romance and customs, expressed in popular forms and using Quichua and Ecuadorian expressions in

18 'Omitida la infinidad de especies, unas excelentes para enmaderados de casas: otras para el ordinario trabajo de carpinteros: otras para la fábrica de navios; otras cuyos nombres apenas saben los operarios [Jesuitas] de las particulares provincias apuntaré algunas pocas de las más nombradas' (Mera, Obras de Juan Leon Mera, vol. 1, p. 118). He ends this section: 'Omito innumerables especies de maderas, por ignorar los nombres' (p. 122).

19 Ibid., p. 135. 
Spanish. ${ }^{20}$ Mera promises that the poetry collection gives the 'moral portrait of the people', and is a vital part of civil and political life that should take its rightful place in Ecuador's literary canon. ${ }^{21}$

Ángel Rama observed that during the nineteenth century in Spanish America, the study of philology proliferated, and many national institutions concerned with regulating national languages were established. Such concern about linguistic matters had to do with the post-independence Spanish-American lettered city's preoccupation with national languages as 'effective instruments for disciplining the symbolic order of national cultures'. ${ }^{22}$ Mera, one of the founding members of Ecuador's Academia de la Lengua and a corresponding member of Spain's Real Academia de la Lengua, was a pioneer in championing the Quichua language, although, as Regina Harrison and others have demonstrated, Mera's relationship to Quichua was complex. ${ }^{23}$ For example, Mera's acts of collection, compilation, editing, translation and analysis of Ecuadorian popular poetry, including poetry in Quichua, reveal an impulse to historicise and theorise such productions as a vital component of national literature. Most important, the Cantares and Melodias indigenas collections value contemporary indigenous cultural production as an authentic expression of Ecuadorian national literature, instead of viewing indigenous works as irrelevant, incomprehensible, inferior, or above all, products of an irrecoverable past.

For both Velasco and Mera, Quito's indigenous peoples - through their culture, language and knowledge of the natural world - are an essential ingredient of the territory's identity. Velasco and Mera both look to the long-vanished Scyris for a noble story about the past, and both lament the poverty and ill treatment of their contemporary indigenous people. Mera finds Velasco's stirring tales of ancestral heroism attractive, and he borrows extensively from the Jesuit's tale of pre-Hispanic exploits for Cumandá, 'La virgen del sol' and various other Indianist poems. Given Mera's Catholic triumphalism, he is especially drawn to the purity of the Scyris' religion, including the unadorned worship of the Sun, and the chastity of the Chosen Virgins. Velasco chooses to emphasise the purity of Quiteño religion, before it is adulterated by impious Incan impositions, but he is also interested in portraying the Scyris' enlightened manner of government, which is less interesting for Mera's romance. The Scyris provide colour and novelty to European literary forms, although Mera, conscious of his European audience, greatly reduced the use of Quichua words and footnotes in the 1887,

\footnotetext{
20 Mera, 'Prólogo', p. 26.

21 Ibid., pp. 39-40.

22 Rama, R. 1996, The Lettered City, Translated and edited by J. C. Chasteen, Duke University Press, Durham, NC.

23 Harrison, R. 1996, Entre el tronar épico y el llanto elegíaco: simbología indígena en la poesía ecuatoriana de los siglos XIX-XX, Ediciones Abya-Yala, Quito.
} 
second edition of 'La virgen del sol'. The Scyris give Velasco's eighteenthcentury Creole compatriots a noble past to take pride in, and nourish Mera's Americanist romanticism in the next century.

While Mera's backward-looking works anchor the Ecuadorian Indian in the glory of the past, or in the exoticism of the distant jungle, he does provide a small measure of contemporary social critique in the story 'Historieta' and the poem 'La madre y el hijo', both set in the highlands. ${ }^{24}$ 'Historieta' exposes republican Ecuador's forced indigenous labour system, the concertaje, in this story of a formerly prosperous smallholding Indian who loses his land and possessions to the depredations of the labour recruiter, the local priest, mayor and other officials of highland Ecuadorian life. In the poem, an indigenous mother laments the fate that is sure to befall her young son: a lifetime of working like a mule, under the whip, and producing wealth on someone else's land. While Mera supported García Moreno's modest attempts at legislating for indigenous labour protection in $1869,{ }^{25}$ the poem and the story both express a 'tragic sense of history' in which not much can change for the better for Ecuador's indigenous population. As in Cumandá, here the Indians must wait for redemption in the afterlife. ${ }^{26}$

The pro-indigenous sentiments expressed in the poem and the story complicate Mera's nostalgic vision of noble 'Ecuadorian' Indians as cultural and historical ancestors of nineteenth-century Ecuadorians, but those works do not offer any alternative means of configuring the nation in the republican present. In fact, Mera's works express a yearning to return to colonial forms of social hierarchy. ${ }^{27}$ For example, in Cumandá, Mera finds metaphors for organising the nation in the harmonious Catholic family, in small farmers, and in the mission, ignoring the increasing power of large landholding, export-oriented estates that put pressure on Indian lands. In the novel, he expresses regret at the loss of the Jesuit missions, as he describes the state of one Dominican mission, Andoas, in 1808. The missionaries have drawn the Indians into town life from the jungle, and each family, carefully Christianised, inhabits its own house and cultivates its own small plot. He spells out the role of the Church in civilising the Indians and inducing them to be part of national life: 'Los sacerdotes que evangelizaron en esas tribus nómades les enseñaron la estabilidad y el amor a la tierra nativa, como bases primordiales de la vida social. ${ }^{28}$ He provides a few picturesque details of mission life, using indigenous words to describe materials for buildings and

24 Mera, J. L., 'Historieta', in V. Corral (ed.), Juan León Mera, pp. 59-68; poem quoted in Harrison, Entre el tronar épico y el llanto elegíaco, pp. 72-6.

25 Harrison, Entre el Tronar épico y el llanto elegíaco, pp. 76-9.

26 Valdano, J. 1995, 'Pecado y expiación en Cumandá', in Bazos Barrera (ed.), Juan León Mera, pp. 53-4.

27 Cornejo Polar, A. 1994, Escribir en el aire. Ensayo sobre la heterogeneidad socio-cultural en las literaturas andinas, Horizonte, Lima, pp. 124-30.

28 Mera, Cumandá o un drama entre salvajes, p. 67. 
explaining the Indians' hunting and agricultural practices, along with their harmonious Christian communal life. But again, present-day cares creep into the late-colonial setting, as Mera bemoans the loss of those missions for national life: ‘Oh, felices habitantes de las solitarias selvas en aquellos tiempos! ¡Cuánto bien pudo haberse esperado de vosotros para nuestra querida Patria a no haber faltado virtuosos y abnegados sacerdotes que continuasen guiándoos por el camino de la civilización a la luz del Evangelio! ¡Pobres hijos del desierto!' ${ }^{29}$ Mera goes on to lay the blame for the neglect of the jungle and its inhabitants, not on the Indians, but rather on 'civilised society' and governments that ignore the Oriente. ${ }^{30}$ Mera would have found ample evidence in Velasco's work of successful missionaries and harmonious towns full of smallholding Indians, each layer of society occupying its proper place, according to the Jesuit's elite notions of how society should be organised.

Mera and Velasco share the conviction that the Catholic Church and its besttrained cultural brokers, the Jesuits, are the perfect instruments for instilling civilisation and unifying the territory. Velasco spells out his order's contributions in a map that accompanies the Historia del Reino de Quito, in which he details the towns, cities, missions, and natural features that make up his homeland. The more settled coastal and highland areas are dotted with toponyms, as are many affluents of the Amazon Basin region. Borders are clearly delineated: the Pacific Ocean to the west, the provinces of Popayán and New Granada to the north, Lima to the south and east, and Portuguese territories to the south-west. One north-western territory stands out. Labelled 'Países bárbaros poco conocidos', this great swath of land bisected by the Equator graphically illustrates a confluence of Velasco's representational and historiographical strategies. The map reveals a patriotic landscape that unites Velasco's concerns about territoriality, knowledge, mastery and civilisation. His conception of geography pits an American natural landscape domesticated by 250 years of Spanish rule against a stretch that remains unknown and therefore barbarian. The map draws attention to the Jesuit's claim that his order's labours in fields of knowledge and tangled jungle fields populated by non-Christians have brought vast territories under the control of the Spanish Crown and numberless souls to the Christian, civilised fold. Velasco's cartography of the possible maps a representational strategy based on fields of knowledge-history, natural history, linguistics, ethnography - that shape the Kingdom of Quito's natural, human and epistemological boundaries. Finally, the map graphically illustrates how the Spanish Crown has abandoned strategies - and strategists - known to produce desired results. Velasco shows - both in prose and in this carefully drawn 'Mapa general de las provincias de Quito' - that the exiled Jesuits have been instrumental in creating a promised land of this region of America, and 
that with their absence, human, spiritual and physical resources go untapped, are lost to the Portuguese, or remain mired in or revert to backwardness and savagery. ${ }^{31}$

Velasco opens the first volume of his Historia, the Historia natural, with an affirmation of the Kingdom of Quito's natural gifts, and he immediately links Quito's natural and political history. His sweeping gaze takes in the whole of his patria, and Velasco connects the knowledge to the knower with an 'I' statement, thus assuring himself an identity as what Antony Higgins has called a 'criollo subject of knowledge' $:^{32}$

El Reyno de Quito, noble porción del Nuevo Mundo, célebre entre los escritores, por su situación bajo la Tórrida Zona: por la sin igual elevación de su terreno: por su benigno clima bastantemente ponderado: por la natural riqueza de sus vegetables, frutos: por el inestimable Tesoro de sus preciosos metales; y por haber sido el teatro principal de las antiguas, y modernas revoluciones de Estado, es el que voy a describir sucintamente. ${ }^{33}$

These opening words produce the patria on the page and in his reader's imagination. After describing the geographical situation, Velasco shows how the land and its history are connected, by providing a summary of how the King dom of Quito's borders were expanded through conquest and confederation. Velasco establishes the legitimacy and naturalness of Quito's contours, from pre-Incan times to the Quito-born Atahualpa's just claim to the Incan Empire, finishing with its greatest expansion, by Spaniards from the sixteenth to the eighteenth century. Velasco insists that Quito is not only blessed by nature; its political history is also singularly rich and deserving of exposition and praise. Through his magisterial representation of Quito's bountiful natural resources, Velasco constructs a subject of knowledge uniquely qualified to interpret this abundance and to understand the special natural laws that operate in America.

31 The map's full title is 'CARTA GENERAL de las provincias del QUITO PROPIO de las orientales adjuntas y de las Misiones del Maranon [sic], Napo, Pastaza, Guallaga, y Ucayale DELINEADA Según las mejores Cartas modernas y observaciones de los Académicos y Misioneros Por el Presb ${ }^{\circ}$ D. Juan de Velasco para servir a su Historia del Reino de Quito. Año de 1789.' In Velasco, Historia del Reino de Quito en la América meridional, vol. 1 .

32 Higgins, A. 2001, Constructing the Creole Archive. Subjects of knowledge in the Bibliotheca mexicana and the Rusticatio mexicana, Purdue University, West Lafayette, Ind.

33 Velasco, Historia del Reino de Quito en la América meridional, vol. 1., p. 49. As Cañizares observes: 'It would be impossible to understand the structure and configuration of this land, Velasco maintained, "without first admiring the effort made by nature to privilege it with its greatest works. The Kingdom of Quito", Velasco insisted, "can glory itself of having features that no other part of America or any other part of the globe can equal". Quito was unique because nature had elected it to have the highest mountain, be the source of the largest river, and enjoy the most temperate climate on earth.' In Cañizares, J. 1998, Nation and nature: patriotic representations of nature in late colonial Spanish America, Working Paper No. 98-31, International Seminar on the History of the Atlantic World, 1500-1800, Harvard University, Cambridge, Mass., p. 5. 
Furthermore, the utopian configuration of American space as bounteous provides Velasco with a blueprint for remedying the ills facing his deteriorated patria.

In his Ojeada histórico-critica de la poesía ecuatoriana, Mera offers his judgment of Velasco's poetry and history, finding both somewhat defective: 'Mas, por desgracia, en punto a su historia, si merece mucho aprecio como narrador noticiosos y justiciero, no hallamos al pensador que con juicio recto sabe sacar lecciones provechosas de moral y filosofía de los acontecimientos que presenta al lector.' ${ }^{34}$ Mera, and other members of Ecuador's lettered city, knew what moral and philosophical lessons to draw from Velasco's foundational history, which is mentioned in patriotic terms in the Ecuadorian press from 1840 on, and published with state backing in 1841-45.

Mera wrote about literary patriotism in a letter to his son J. Trajano Mera, published in 1889 in the Revista Ecuatoriana, a journal co-edited by Trajano and Vicente Pallares Peñafiel. Juan León counsels his son about the abnegation, dedication and patriotism necessary in an Ecuadorian writer. He compares the literary career with a dangerous jungle journey: 'Ser literato entre nosotros es como meterse en el corazón de las selvas trasandinas: aqui halla uno una espesura impenetrable, allá un río que es preciso esguazar con riesgo de ahogarse, acullá una red de lianas que le amarran los pies o medio le estrangulan.' Even after one escapes from the jungle, the effects of its trials linger: 'siente al mismo tiempo el escozor de las picaduras que le han dado millones de bichos venenosos, y le zumban todavía a los oídos las voces destempladas de las alimañas que le salieron al paso.' Nonetheless, he does not dissuade Ecuadorians from pursuing such a carreer; in fact, he advises that all learning and literature be in service to the patria: 'Es preciso darlo todo a la patria, aunque la patria no nos dé nada; es preciso ser de ella, aunque ella nos rechace; es preciso no buscar otra retribución que la justicia de la posteridad y el reposo en el seno de Dios.' Mera portrays the Ecuadorian republic of letters as a dangerous jungle full of ingrates, but he also notes that the literary career is a heroic mission and patriotic duty whose virtuous practitioners will be rewarded by God - and future members of the patria. Perhaps this is what happens with Velasco, who died in poverty in Italy, his work unpublished in his lifetime, but who has been rescued by later generations of patriotic men of letters (and a very few women). In a similar vein, Mera has suffered in the estimation of some Ecuadorians because of his identification with García Moreno's particular brand of theocratic conservative rule, and his conflicted portrayal of indigenous Ecuadorians either as romanticised noble savages or as doomed serfs.

Velasco's history and Mera's novel Cumandá serve to domesticate 'empty spaces' for the patria and to legitimate them as national territories. (In fact,

34 Mera, Ojeada histórico-crítica de la poesía ecuatoriana, p. 176. 
Velasco's map would later prove useful in Ecuador's border disputes with Peru over those very territories.) In the first chapter of Cumandá, narrated from the point of view of 'el viajero', the narrator casts an appropriating gaze over what is alternately the green hell and locus amoenus of the jungle, replete with exuberant vegetation of difficult penetration, dark and uninhabited, save for savages. The jungle inspires a few sensitive souls to poetry, but in general the solitude assures the 'traveller' that '[e]res dueño de ti mismo y verdadero rey de la naturaleza: estás en tus dominios, haz de ti y de cuanto te rodea lo que quisieres. Excepto Dios y tu conciencia, aqui nadie te mira ni sojuzga tus actos. ${ }^{.35}$ No-one will judge our traveller - that is, except the 'savage', whose indomitable character has been formed by his surroundings. The appropriating gaze, inscribed into this 'national romance', is inspired by Mera's reading of Velasco, where he would find tales of Jíbaro rebellion and Jesuit heroism. Velasco's mission history and Mera's foundational fiction instil those far-flung territories into their reader's imagination as part of a unified Quiteño - and later Ecuadorian-territory, whose initial boundaries were traced by Velasco's Scyris, Incas, and early Spanish conquerors - and whose consolidation could be assured by republicanera missions and theocratic policies. 